\title{
ZFHX3 Gene
}

National Cancer Institute

\section{Source}

National Cancer Institute. ZFHX3 Gene. NCI Thesaurus. Code C115424.

This gene is involved in myoblast and neuronal differentiation. 